\title{
ГОТОВНІСТЬ УЧИТЕДЯ ДО ПЕДАГОГІЧНОГО СУПРОВОДУ ОБДАРОВАНИХ УЧНІВ У КОНТЕКСТІ ОСВІТНЬОЇ ДІЯЛЬНОСТІ
}

У статті розглянуто проблему готовності учителя до педагогічного супроводу обдарованих учнів у закладах загальної середньої освіти. Автор аналізуе поняття готовності, спираючись на розвідки відомих украйнських учених, і погоджуеться з ними в тому, щзо цееи феномен е складним синтетичним утворенням який формуеться в педагогічній діяльності. Автор також зазначае, що педагогічний супровід обдарованих учнів є по суті є інноваційною діяльністю, оскільки в освітній політиці не виокремлювалися лінії, пов'язані з обдарованістю. Отже, є потреба привернення уваги до проблематики, пов'язаної з навчанням і розвитком обдарованих дітей.

3 метою візуалізації змісту досліджуваної проблеми автор застосовуе методологію моделювання. Переконливо викладені підходи до створення педагогічної моделі дозволяють автору мінімізувати зоровий ряд $і$ в той же час максимально наповнити його змістовим навантаженням. Подана у статті модель готовності вчителя до педагогічного супроводу наочно демонструе структуру феномена й основні комунікативні зв'язки, щзо відіграють провідну роль у його формуванні.

Особливого значення автор надае операційному аспекту готовності вчителя до здійснення педагогічного супроводу обдарованих дітей $i$ юні. Наголошено на необхідності спеціальних знань про обдарованість, їі види $і$ прояви у дітей, характерні особливості контингенту обдарованих, способи розвитку обдарованості тощо. Особливий акцент зроблено на комунікативній компетентності учителя, яка є складовою продуктивної співпраці з учнями в їх особистісному розвитку.

На основі результатів діяльності експериментальних майданчиків Інституту обдарованої дитини Національної академії педагогічних наук України зазначено про обов'язковість спрямування політики закладу загальної середньої освіти на пошук ірозвиток обдарованих дітей та об'єднання зусиль педагогічного колективу, адміністрації та соціально-психологічної служби на досягненні єдиної спільної мети - розвитку обдарованості учнів.

Ключові слова: обдарованість, педагогічний супровід, готовність учителя, структурна модель, заклад загальної середньої освіти.

Постановка проблеми. Викдиком сучасного етапу розвитку суспільств, особливо тих, що претендують на статус розвиненої країни, є пошук і розвиток обдарованих дітей і молоді. Цю діяльність можна вважати розпочатою в незалежній Україні з утворенням Малої академії наук (2000), пізніше трансформованої у Національний центр «Мала академія наук» (2010) [13], та Інституту обдарованої дитини у складі Національної академії педагогічних наук України (2007) [5]. 3'явилися наукові розвідки, що окреслювали певні сегменти вивчення й освітньо-педагогічної діяльності, пов'язаної з обдарованістю - О. Є. Антонової, О. І. Кульчицької, В. О. Моляка, О. А. Музики, та ін. Разом із тим дослідження не охоплюють важдивого складника діяльності з обдарованими учнями - педагогічного супроводу обдарованої дитини в умовах закладу загальної середньої освіти. Здебільшого розвиток обдарованих дітей і юні відбувається без здійснення цілеспрямованої, спланованої, покрокової діяльності з боку педагогічного колективу навчального закладу. Кількість шкіл, орієнтованих

*) Ткаченко Л.I.

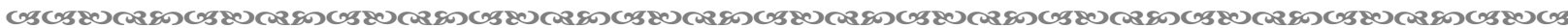
215 
на поглиблений рівень вивчення певних предметів шкільної програми, спеціалізованих шкіл, ліцеїв, гімназій порівняно невелика. Робота має бути системною, охоплювати весь період навчання у $33 \mathrm{CO}$ - від вступу до початкової школи й до випуску зі старшої [15], із залученням до діяльності усіх стейкхолдерів - батьків, працівників управлінсько-освітньої сфери громад, позашкільної освіти, науково-педагогічних працівників закладів вищої освіти, наукових працівників наукових установ тощо. Проте треба наголосити, що центрадьним складником цієї діяльності є цілеспрямований педагогічний уплив учителя у суб'єкт-суб'єктних відносинах учителя і учня. Від того, наскільки вчитель компетентний, вмотивований і здатний проводити діяльність з навчання й розвитку обдарованої дитини, настільки можна 3 упевненістю говорити про позитивні результати такої діяльності.

Аналіз досліджень. Проблема готовності до педагогічної діяльності розглядалася багатьма дослідниками (Г. В. Бєленька, Т. Г. Жаровцева, Н. В. Кічук, С. А. Аитвиненко, А. Ф. Ліненко, В. В. Нестеренко. О. М. Пехота, Т. П. Танько, В. І. Шахов та ін.), кожний 3 яких обгрунтовував і акцентував певний аспект професійної готовності. Наприклад, А. Ф. Ліненко розуміє готовність як цілісне утворення, що характеризує емоційнокогнітивну і водьову мобілізаційність суб'єкта в момент його включення в діяльність певного спрямування [8, с. 56]. С. А. Аитвиненко формулюе готовність до соціальнопедагогічної діяльності, якою в цілому і є діяльність учителя, як результат професійнопедагогічної підготовки, інтеградьне багаторівневе динамічне особистісне утворення [9, с. 16]. Г. В. Троцко, вивчаючи готовність майбутніх педагогів до виховної діяльності (чим значною мірою і є педагогічний супровід обдарованих дітей і юні), визначає цей феномен як цілісне, складне, особистісне утворення, що забезпечує високий рівень педагогічної діяльності й охоплюе професійно-педагогічні погдяди і переконання, професійну спрямованість психічних процесів, професійні знання, уміння долати труднощі, оцінювати наслідки своєї праці, професійно самоудосконалюватися [17, с. 15]. Останне визначення найбільш широко охоплює перелік складових готовності вчителя. Узагальнюючи розвідки, можна визначити готовність до професійної педагогічної діяльності як синтетичне соціально-педагогічне утворення особистості учителя, що вкдючає індивідуально-психодогічні якості особистості і професійно-педагогічну компетентність, які сукупно забезпечують здійснення цілеспрямованої педагогічної діяльності на високому рівні. Готовність як нова якість особистості виникає у процесі певної діяльності.

Метою статті є визначення складових готовності вчителя до педагогічного супроводу обдарованих учнів зі застосуванням методології моделювання.

Викдад основного матеріалу. Набуття й розвиток фахових компетенцій як складник готовності (компетентнісний підхід) у системі педагогічної освіти, в тому числі й неперервної, є предметом наукових розвідок у різних аспектах: філософськоосвітніх - I. Д. Беха, С. У. Гончаренка, педагогів початкової школи - Н. М.Бібік, О. Я. Савченко, дошкільної освіти - А. М. Богуш, фахової підготовки у вищій школі С. О. Сисоєвої та ін.

Зазначимо, що педагогічний супровід обдарованих учнів треба віднести до інноваційної педагогічної діяльності, оскільки нині таке завдання перед педагогічним колективом школи й учителем постає як нове й потребує від учителя формування компетенцій зовсім іншого порядку, ніж традиційна педагогічна діяльність у З3СО. На думку О. В. Сухомдинської, «питання розвитку здібностей і здатностей дітей не мало однозначного вирішення, або ж взагалі не ставилося у вітчизняному шкільництві» [14, с. 8]. Тому звернемося до розвідок, що містять досдідження інноваційної педагогічної діяльності.

Так, І.В. Гавриш окреслюе готовність до інноваційної професійної діяльності як інтегративну якість особистості вчителя, що виявляється в діалектичній єдності всіх структурних компонентів, властивостей, зв'язків і відносин; складне особистісне us 216 
утворення, що $\in$ умовою $\mathrm{i}$ регулятором успішної професійної діяльності вчителя [4, с. 26]. О. М. Пехота, досліджуючи готовність до професійного саморозвитку, що тісно пов'язаний із інноваційною діяльністю, визначає феномен готовності як складноструктуроване утворення, що забезпечує необхідні внутрішні умови для успішного професійного саморозвитку майбутнього вчителя [12, с. 16].

Готовність до будь-якої практичної дії 3 точки зору психології, що якраз і узагальнює попередні формулювання, окреслює С. Д. Максименко: це стан мобілізації психологічних і психофізіодогічних систем дюдини. що забезпечують виконання певної діяльності. У психології виокремлюють кілька аспектів до готовності:

а) операційний - володіння певним набором способів дії, знань, умінь і навичок, а також мождивості набуття нового досвіду в межах певної діяльності;

б) мотиваційний - система спонукальних якостей щодо певної діяльності (мотиви пізнання, досягнення, самореалізації тощо);

в) соціально-психологічний - рівень зрілості комунікативної сфери особистості, вміння здійснювати колективно розподіяену діядьність, уникати деструктивних конфліктів та ін.;

г) психофізіологічний - готовність систем організму діяти в даному напрямі.

Кожний стан готовності до діяльності визначається сполученням різних факторів, що визначають різні рівні, аспекти готовності. Залежно від змісту діяльності та умов iï здійснення провідним може стати один із таких аспектів [3, с. 137-138].

Розглянемо кожний $з$ аспектів. Операційний аспект готовності вкдючає наступні знання й базовані на них компетентності:

- знання про те, що таке обдарованість, які ї̈ види, якими характерними рисами відрізняються обдаровані учні;

- знання про способи розвитку обдарованості;

- здійснення перманентного педагогічного спостереження (його планування й проведення) за учнями на всіх етапах їхнього навчання у закладі загальної середньої освіти;

- розпізнавання і репрезентація сильних і слабких сторін конкретної обдарованої дитини та коригування педагогічних впливів;

- комунікативні навички спілкування з обдарованими учнями, а також їхніми батьками;

- особистісно зорієнтований підхід до навчання обдарованих учнів;

- спрямування обдарованої дитини до розвитку обдарованості у позаурочній і позашкільній діяльності;

- залучення обдарованих дітей і юні до позаурочної та позашкільної діяльності;

- залучення обдарованої дітей і юні до шкільних і позашкільних змагань у сферах їхньої обдарованості;

- залучення обдарованих учнів до самостійної дослідницької діяльності;

- залучення обдарованих учнів до роботи у Малій академії наук.

Мотиваційний рівень діяльності 3 обдарованими учнями залежить від самомотивації вчителя та зацікавленості адміністрації закладу в роботі з обдарованими. Якщо заклад, завдяки своєму типу чи/і цілеспрямованій політиці адміністрації, орієнтований на залучення й роботу з обдарованими дітьми, то зазвичай у закладі сформовано систему роботи з обдарованими, в яку вкдючено адміністрацію, предметні кафедри або шкільні методичні об'єднання, персонально учителів, шкільного психолога. I тоді мотиваційний рівень підтримується стилем і ритмом діядьності всього загальноосвітнього закладу, що знаходить відображення у (циклічних) планах роботи закладу. Співпраця 3 експериментальними майданчиками - закладами загадьної середньої освіти - доводить, що позитивний ефект розвитку обдарованих дітей і юні спостерігається в тих закладах, де існує системна робота, очодювана адміністрацією. Якщо традиції, орієнтованої на виявлення й роботу з обдарованими учнями в закладі us 
немає, то ініціативу, що ії виявляють окремі вчителі, розвивати надзвичайно складно, і така несистемна діяльність рідко приносить бажані резудьтати.

До мотиваційного аспекту віднесемо й перманентне підвищення кваліфікації учителя в різний спосіб - формальний, неформальний, інформальний. Зазначимо, що компетентність у роботі з обдарованими дітьми вимагає постійного професійного й особистісного зростання з урахуванням нарощуваних знань про обдарованість, систем діяльності в галузі пошуку і розвитку обдарованих дітей і молоді в різних країнах світу, результатів здійснених досліджень в Україні тощо, а також провідних тенденцій інформатизації освіти. Зауважимо, що мультимодадьна грамотність, пов'язана із інформатичною компетентністю [6], зараз стає неодмінним складником професійного рівня спілкування з учнями.

Надзвичайно важдивим є і соціально-комунікативний аспект готовності учителя до роботи з обдарованими учнями. I тут важдивими $є$ не лише педагогічна компетентність на рівні педагогічної майстерності зацікавдювати, мотивувати, спонукати, заохочувати, підтримувати обдаровану дитину, а й уміння слухати, чути, розуміти, сприйняти відмінну від власної думку, ухвадити альтернативне рішення, аж до визнання вищості обдарованої дитини. Про останнє зазначають автори Р. Ф. Суботнік та ін., називаючи це еміненцією - визнаною перевагою, що має складати мету освіти обдарованих [20].

Психофізіологічний рівень передбачає культуру здоров'я, культуру харчування, стресостійкість, запобігання професійному вигоранню, що в цілому відноситься до загальної культури особистості вчителя.

Постійне спілкування 3 обдарованими учнями, підтримання 3 ними стосунків співпраці, обміну думками тощо - суб'єкт-суб'єктна взаємодія, е провідною діяльністю педагогічного супроводу. Саме продуктивна комунікація допомагає виявити проблеми та усунути їх, налаштовує обдаровану дитину на власний розвиток і водночас спонукає учителя до постійного саморозвитку. Це, сукупно 3 освітньо-виховною, складає практичну складову педагогічного супроводу обдарованої особистості.

Окремо потрібно наголосити на важливості педагогічного спостереження за обдарованими дітьми і піддітками на всіх етапах їхнього перебування в освітньому закладі й постійного аналізу їх навчальної діяльності та соціальних зв'язків [16].

Перед презентацією структурної моделі готовності учителя до роботи з обдарованими учнями наведемо кілька тез щодо створення педагогічних моделей.

Проблему моделювання у педагогіці глибоко опрацьовували К. М. Гнезділова, С. У. Гончаренко Є. О. Лодатко, В. І. Міхеєв й ін. Застосування педагогічних моделей для розв'язання конкретних освітніх проблем соціалізації демонструють Б. М. Андрієвський (розвиток професійної майстерності викладача), Г.У. Матушинский (подготовка до професійної діяльності у вищій школі), Н. М. Самборська (формування соціальнокомунікативної компетентності майбутніх фахівців), Я. Б. Сікора (формування професійної компетентності майбутнього вчителя), М. І. Якібчук (розвиток толерантності у студентів) та ін.

Наведемо визначення застосовуваних категорій. Під моделлю розуміють уявну або матеріально-реалізовану систему, котра відображає або відтворює об'єкт дослідження (природний чи соціальний) і здатна змінювати його так, що їі вивчення дає нову інформацію стосовно цього об'єкта. За властивостями моделі мождиво дізнатися про суттєві властивості об'єкта [3, с. 516].

Метою створення структурної моделі готовності до педагогічного супроводу є окреслення умов формування готовності учителя до діядьності з обдарованими учнями.

Об'єкт модедювання - система суб'єкт-суб'єктних відносин усіх учасників освітнього процесу з метою максимального розвитку обдарованої дитини у 33СО. 
Предметом моделювання є профіль особистісних і соціальних складників готовності учителя задля максимального розвитку обдарованої дитини.

Спираючись на В. І. Міхєєва [11], зазначимо, що моделювання в педагогіці має кілька змістових діній: гносеологічну, у якій модель відіграє роль проміжного об'єкта упроцесі пізнання педагогічного явища; загальнометодологічну, яка виявляе й доповнюе зв'язки й відношення між різними елементами освітнього процесу на різних рівнях їх опису і вивчення; психологічну, яка дозволяе вести опис різних сторін навчадьної і педагогічної діяльності та виявдяти на цій основі психодогопедагогічні закономірності.

У нашому випадку гносеологічна лінія дозволяе з' ясувати, яким чином набувається готовність учителя до педагогічної взаємодії з обдарованою дитиною у З3СО (педагогічного супроводу), які складники цього процесу, який його зміст, які суб'єкти освітньої системи беруть участь у їі здійсненні.

Загальнометодологічна лінія актуалізує методи інтерактивної дії суб'єктів освітньої діяльності з метою організації ефективної співпраці учителя й учня. Психологічна дінія окреслюе шляхи й методи психологічного супроводу педагогічної інтерактивної взаємодії учителя і обдарованого учня.

Найважливішим фактором формування інтерактивної сфери діяльності дюдини вважає спілкування В.Г. Кремень. Учений зазначає, що це - «взаємодія двох (або більше) людей, спрямована на узгодження і об'єднання їхніх зусиль 3 метою налагодження відносин і досягнення загального результату. Спілкування є не просто дією, а саме взаємодією: воно здійснюється між учасниками, кожний з яких рівною мірою є носієм активності й передбачає іï у своїх партнерах» [7, с. 424]. Великого значення надає комунікативній діяльності Р. А. Арцишевський, зазначаючи, що вона є формою бездічі найрізноманітніших стосунків між людьми, у яких «відбуваються обмін діяльністю, інформацією, досвідом, уміннями і навичками, а також результатами діяльності» [1, с. 335]. Особливістю комунікативної діяльності Р. А. Арцишевський вважає і те, що вона передбачає більшу, ніж в інших видах діяльності, активність сторін, що взаємодіють, тому повноцінне спілкування можливе лише за умови, що кожен 3 його учасників є обов' язково суб'єктом [там само].

Таким чином, модель у цілому відображає не лише складники готовності до педагогічної взаємодії, а й комунікативні зв'язки між учасниками освітнього процесу. Ці комунікативні зв'язки сприятимуть, з одного боку, створенню освітньо-розвивального простору 33СО, а з другого - розвитку комунікативної компетентності як складової адаптації і соціалізації обдарованої дитини, що е підгрунтям іiі подальшої успішної самореалізації впродовж життя.

Треба зауважити. що модель завжди має високий ступінь абстрагування й узагальнення, аби бути придатною для застосування, оскільки освітній процес крім об'єктивних складників завжди включає і суб'єктивні характеристики й обставини, врахування яких дозводить адаптувати модель до кожної конкретної ситуації. Тут пошлемося на зауваження Є. О. Лодатка [10] щодо педагогічної моделі та їі придатності: «...Розроблена модель педагогічного явища (об'єкта чи процесу) має шанс на апробацію і практичне «виживання» в умовах реального навчально-виховного процесу дише за умови достатнього узагальнення досліджуваних змістовних і структурнопроцесуальних компонентів, тобто високого рівня абстрагування. Якщо модель побудована в такий спосіб, то в подальшому не викдючається мождивість відмінних iii інтерпретацій і розробки на цій основі різних (у певному розумінні) технологій реалізації модельних рішень. При зниженні рівня абстрагування на етапі побудови моделі кількість їі змістовних і структурно-процесуальних компонентів суттєво зростає, що тягне за собою нездоланне ускиаднення етапу інтерпретації, i як правило, унеможливлює розроблення прийнятої технології реалізації модельних рішень». Відтак, ускладнення й надмірна деталізація не можуть забезпечити ні підвищення

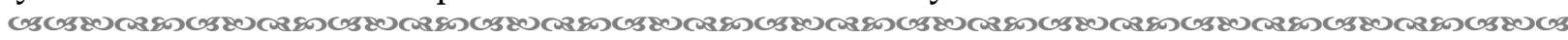
219 
інформативності моделі, ні поглиблення іiі розуміння.

Отже, модель готовності учителя до педагогічного супроводу обдарованих учнів може бути представленою таким чином (рис. 1).

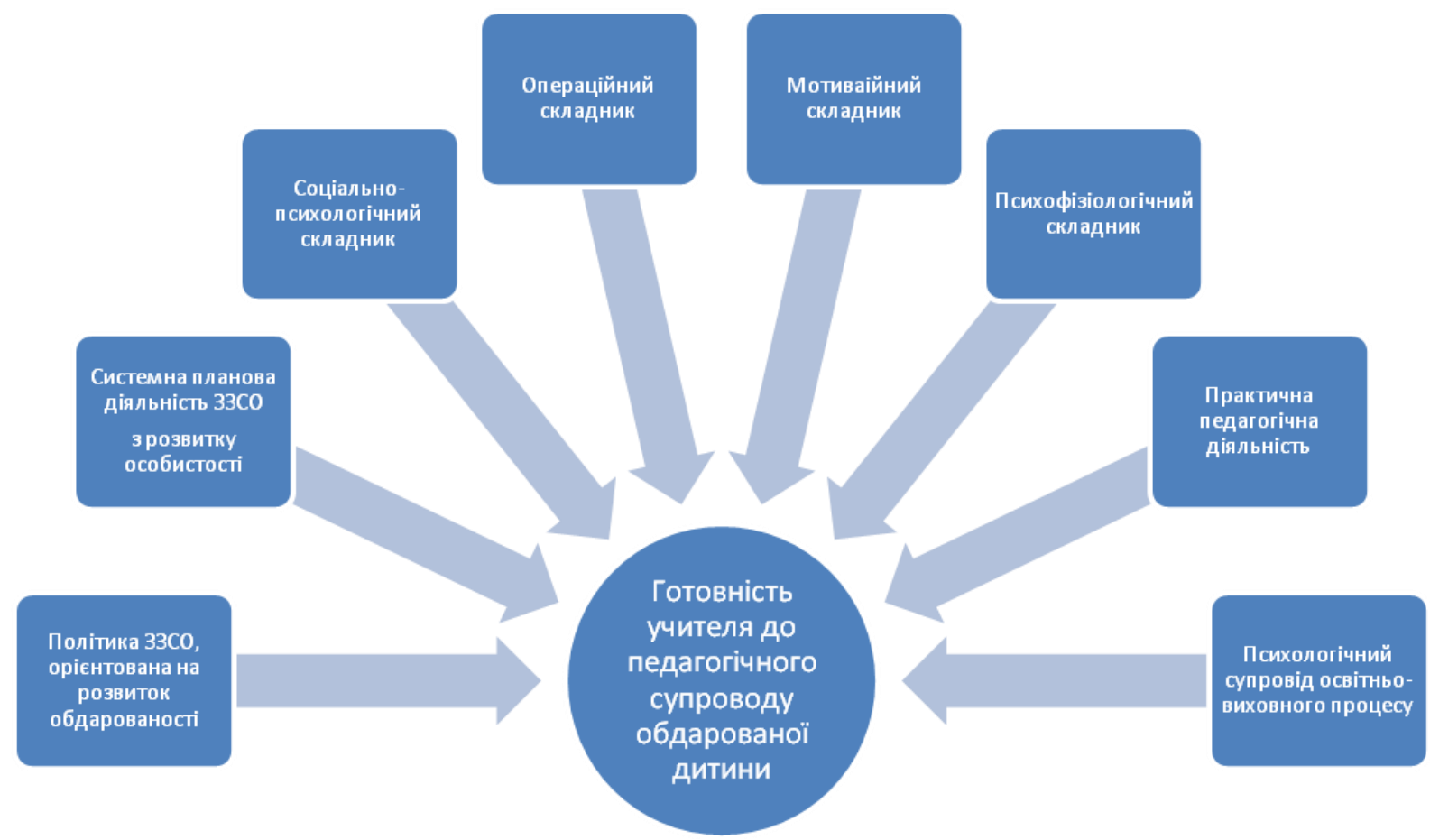

Рис. 1. Модель готовності учителя до педагогічного супроводу обдарованої дитини

Раніше ми схарактеризували особистісні складники готовності вчителя. Тепер зосередимося на складниках, що стосуються опосередкованого впдиву на готовність до роботи з обдарованими учнями.

Політика 3ЗСО є системоутворювальним чинником всієї діяльності з обдарованими учнями. Саме це характеризує зацікавленість адміністрації і педагогічного колективу закладу й свідчить про формування відповідної корпоративної культури, місії і візії, завдань і шляхів їх розв'язання. У свою чергу це зумовлюе відповідне планування внутрішньої системи підвищення якості освітньовиховної діяльності та заходів із внутрішнього контродю за якістю педагогічного супроводу обдарованих дітей і юні. У першу чергу до системи підвищення якості треба віднести проведення науково-практичних семінарів для педагогічних працівників закладу 3 проблем обдарованості, проведення тематичних педагогічних рад, педагогічних консиліумів тощо. Важливим з боку адміністрації закладу є заохочення учителів до професійного зростання шляхом участі у науково-практичних конференціях, майстер-класах, тренінгах, заходах з обміну досвідом та ін.

Психологічний супровід з боку психологічної (соціально-психологічної) служби закладу складає важливий аспект готовності вчителя. Саме психологічна служба має проводити систематичне і системне обстеження стану психодогічної адаптації обдарованих учнів на всіх етапах їхнього дорослішання й розвитку. Це дозволяе здійснювати моніторинг психологічного благополуччя дитини 3 наступною корекцією, якщо в цьому виникає потреба. Швидке адресне реагування психологічної служби закладу допомагає зорієнтувати учителів у проблемній ситуації, визначити шлях іï подолання, окреслити перспективи подальшого розвитку дитини.

Завданням психологічної служби не є відстеження психологічного стану педагогічних працівників закладу, але управлінський досвід керівників, орієнтованих 
на успішність у здійснюваній діядьності 3 розвитку обдарованих учнів, підказуе, що підтримання позитивного налаштування вчителів до роботи з обдарованими та розвиненої емпатії вчителів до обдарованих учнів, а також запобігання професійному вигоранню вчителя є важливими складниками організаційної діяльності адміністрації.

Висновки. Готовність учителя до педагогічного супроводу обдарованих учнів є складним синтетичним утворенням професійних компетентностей, спеціадьно орієнтованих на роботу з обдарованими учнями, і особистісних якостей, які можуть бути реалізованими за умов цілеспрямованої підтримки адміністративноуправдінського та психологічного складників освітньо-виховної діяльності закладу загальної середньої освіти. Наведена модель готовності у стислому вигляді репрезентує складники готовності учителя до педагогічного супроводу обдарованих учнів. Для більш розгорнутого опису потрібен інший формат представлення. Перспективи подальших досліджень полягають у визначенні й експериментальній перевірці карти професійних компетенцій учителя, що матиме відповідну кваліфікацію для роботи з обдарованими учнями.

\section{Список використаних джерел:}

1. Арцишевський Р. А. Філософська антропологія (філософія людини) : навч. посіб. для студ. вищ. навч. закл. У 2 ч. Ч. 2. Луцьк : Волин. нац. ун-т ім. Лесі Українки, 2011. 440 с.

2. Безпалько О. В. Соціальна педагогіка та соціальна робота у сучасному освітологічному $\begin{array}{llllll}\text { просторі. Освітологічний } \text { дискурс. 2011. № 1. } & \text { С. 103-111. URL: }\end{array}$ //nbuv.gov.ua/UIRN/osdys 2011112

3. Енциклопедія освіти / Акад. пед. наук України. Київ: Юрінком Інтер, 2008. 1040 с.

4. Гавриш І. В. Теоретико-методологічні основи формування готовності майбутніх учителів до інноваційної професійної діяльності : автореф. дис. … д-ра пед. наук: 13.00.04 / Дуганський національний педагогічний університеті імені Тараса Шевченка. Харків, 2006. 44 с.

5. Історія інституту. Інститут обдарованої дитини НАПН України: офіц. сайт. URL: http://iod.gov.ua/viewpage.php?page id=4

6. Кремень В.Г. Гносеологія мультимодальності як потреба цифрової сучасності. Історія та білософія освіти в незалежній Украӥні: здобутки і стратегіï: матеріали Всеукр. наук.-практ. конф. 3 міжнар. участю (м. Київ, 20 трав. 2020 р.). Київ, 2020. С. 12-15.

7. Кремень В. Г. Філософія людиноцентризму в стратегіях освітнього простору : монографія. Київ : Педагогічна думка. 2009. 520 с.

8. Аиненко А. Ф. Теория и практика формирования готовности студентов педагогических вузов к профессиональной деятельности : дис. ... д-ра пед. наук: 13.00.01, 13.00.04 / АПН Украины, Ин-т педагогики и психологии проф. образования. Киев, 1996. 403 с.

9. Литвиненко С. А. Теоретико-методологічні засади підготовки майбутніх учителів початкових класів до соціально-педагогічної діяльності : автореф. дис. ... д-ра. пед. наук / Національний педагогічний університет імені М. П. Драгоманова. Київ, 2005. 40 с.

10. Лодатко Є. О. Моделювання в педагогіці: точки відліку. Педагогічна наука: історія, теорія, приктика, тенденції розвитку. 2010. № 1. URL: //intellect-invest.org.ua/pedagog editions emagazine pedagogical cience vypuski n1 2010 st $2 /$

11. Михеев В.И. Моделирование и методы теории измерений в педагогике: монография. Изд. 4-е, доп. Москва: КРАСАНД, 2010. 224 с.

12. Пехота Е. Н. Індивідуалізація професійно-педагогічної підготовки вчителя : автореф. дис. ... д-ра пед. наук: 13.00.04 / АПН України, Ін-т педагогіки і психології проф. освіти. Київ, 1997. $52 \mathrm{c}$.

13. Про МАН. Мала академія наук України: офіц.. сайт. URL: http://man.gov.ua/ua/about_the_academy/jasu

14. Сухомлинська О.В. Ставлення до дитячої обдарованості в історії розвитку вітчизняної освіти: приклад чи ілюзія. Підтримка та супровід обдарованих учнів в сучасному інформаційноосвітньому просторі: матеріали Всеукр. наук.-практ. онлайн-конф. (м. Київ, 27 жов. 2020 р.). Київ, 2020. С. 7-13.

15. Ткаченко И. І. Адаптація обдарованих учнів у закладах загальної середньої освіти: педагогічний аспект. Рідна школа. 2019. № 5-6. С. 19-24. 
16. Ткаченко Д. І. Розвиток обдарованості як педагогічна проблема. Педагогічний альманах: збірник наукових праць / редкол. В. В. Кузьменко (голова) та ін. Херсон: КВНЗ «Херсонська академія неперервної освіти», 2019. Випуск 44. С. 25-30.

17. Троцко Г. В. Теоретичні та методичні основи підготовки студентів до виховної діядьності у вищих педагогічних навчальних закладах : автореф. дис... д-ра пед. наук : 13.00.04; 13.00.01 / АПН України, Ін-т педагогіки і психології проф. освіти. Київ, 1997. 54 с.

18. Subotnik, R. F., Olszewski-Kubilius, P. \& Worrell, F. C. Rethinking Giftedness and Gifted Education: A Proposed Direction Forward Based on Psychological Science. Psychological Science in the Public Interest. 2011. 12 (1). 3-54.

\section{References:}

1. Artsyshevskyi, R. A. (2011). In Filosofska antropolohiia (filosofiia liudyny): navch. posib. dlia stud. vyshch. navch. zakl. U 2 ch. [Philosophical anthropology (human philosophy): a textbook for students of higher education institution]. (Vol. 2). Lutsk: Volyn. nats. un-t im. Lesi Ukrainky [in Ukrainian].

2. Bezpalko, O. V. (2011). Sotsialna pedahohika ta sotsialna robota u suchasnomu osvitolohichnomu prostori [Social pedagogy and social work in the modern educational area]. Osvitolohichnyi dyskurs, 1, 103-111. Retrieved from //nbuv.gov.ua/UIRN/osdys 2011112 [in Ukrainian].

3. Kremen, V. G. (Ed.) (2008). Entsyklopediia osvity [Encyclopedia of Education]. Kyiv: Yurinkom Inter. [in Ukrainian].

4. Havrysh, I. V. (2006). Teoretyko-metodolohichni osnovy formuvannia hotovnosti maibutnikh uchyteliv do innovatsiinoi profesiinoi diialnosti [Theoretical and methodological bases of formation of future teachers' readiness for innovative professional activity]. (Extended abstract of Doctor's thesis). Luhansk Taras Shevchenko National Pedagogical University. Kharkiv [in Ukrainian].

5. Istoriia instytutu. Instytut obdarovanoi dytyny NAPN Ukrainy. (2020). Ofitsiinyi sait Institutu obdarovanoi dytyny NAPN Ukrainy [Official site of Institute of Gifted Children of NAES of Ukraine]. Retrieved from https://iod.gov.ua/viewpage.php?page id $=4$ [in Ukrainian].

6. Kremen, V.H. (2020). Hnoseolohiia multymodalnosti yak potreba tsyfrovoi suchasnosti [Epistemology of multimodality as a need of digital modernity], Istoriia ta filosofiia osvity $v$ nezalezhnii Ukraini: zdobutky $i$ stratehii: materialy Vseukr. nauk.-prakt. konf. z mizhnar. uchastiu [History and Philosophy of Education in Independent Ukraine: Achievements and Strategies, Proceedings of the All-Ukrainian Scientific and Practical Conference with International Participation]. Kyiv [in Ukrainian].

7. Kremen, V. H. (2009). Filosofiia liudynotsentryzmu $v$ stratehiiakh osvitnoho prostoru [Philosophy of anthropocentrism in the strategies of educational area]. Kyiv: Pedahohichna dumka [in Ukrainian].

8. Linenko, A. F. (1996). Teoriia i praktika formirovaniia gotovnosti studentov pedagogicheskikh vuzov $k$ professionalnoi deiatelnosti [Theory and practice of forming students' readiness of pedagogical universities for professional activities]. (Doctor's thesis). Institute of Pedagogy and Psychology of Vocational Education of the National Academy of Pedagogical Sciences of Ukraine. Kiev [in Russian].

9. Lytvynenko, S. A. (2005). Teoretyko-metodolohichni zasady pidhotovky maibutnikh uchyteliv pochatkovykh klasiv do sotsialno-pedahohichnoi diialnosti [Theoretical and methodological principles of training future primary school teachers for socio-pedagogical activities]. (Extended abstract of Doctor's thesis). Drahomanov National Pedagogical University. Kyiv [in Ukrainian].

10. Lodatko, Ye. O. (2010). Modeliuvannia v pedahohitsi: tochky vidliku [Modelling in pedagogy: starting points]. Pedahohichna nauka: istoriia, teoriia, pryktyka, tendentsii rozvytku, 1. Retrieved from http://intellect-invest.org.ua/pedagog editions e-magazine pedagogic science vypuski $\mathrm{n} 1$ 2010 st 2/ [in Ukrainian].

11. Mikheev, V. I. (2010). Modelirovanie $i$ metody teorii izmerenii v pedagogike: monografiia [Modelling and methods of measurement theory in pedagogy]. Moskva: KRASAND [in Russian].

12. Piekhota, E. N. (1997). Indyvidualizatsiia profesiino-pedahohichnoi pidhotovky vchytelia [Individualization of professional and pedagogical teacher's training]. (Extended abstract of Doctor's thesis). Institute of Pedagogy and Psychology of Vocational Education of the National Academy of Pedagogical Sciences of Ukraine. Kyiv [in Ukrainian]. 
13. Pro MAN. Mala akademiia nauk Ukrainy. (2020). Ofitsiinyi sait Maloi Akademii nauk Ukrainy [Official site of Junior Academy of Sciences of Ukraine]. Retrieved from http://man.gov.ua/ua/about the academy/jasu [in Ukrainian].

14. Sukhomlynska, O.V. (2020). Stavlennia do dytiachoi obdarovanosti v istorii rozvytku vitchyznianoi osvity: pryklad chy iliuziia [Attitude to children's talents in the history of national education: an example or illusion], Pidtrymka ta suprovid obdarovanykh uchniv v suchasnomu informatsiinoosvitnomu prostori: materialy Vseukr. nauk.-prakt. onlain-konf. [Support and development of gifted pupils in the modern information and educational space, Proceedings of the All-Ukrainian scientific-practical online conference]. Kyiv [in Ukrainian].

15. Tkachenko, L. I. (2019). Adaptatsiia obdarovanykh uchniv u zakladakh zahalnoi serednoi osvity: pedahohichnyi aspekt [Adaptation of gifted pupils in general secondary education institutions: pedagogical aspect]. Ridna shkola, 5-6, 19-24 [in Ukrainian].

16. Tkachenko, L. I. (2019). Rozvytok obdarovanosti yak pedahohichna problema [Development of talent as a pedagogical problem]. Pedahohichnyi almanakh, 44, 25-30 [in Ukrainian].

17. Trotsko, H. V. (1997). Teoretychni ta metodychni osnovy pidhotovky studentiv do vykhovnoi diialnosti u vyshchykh pedahohichnykh navchalnykh zakladakh [Theoretical and methodical bases of students' preparation for educational activity in higher pedagogical educational institutions]. (Extended abstract of Doctor's thesis). Institute of Pedagogy and Psychology of Vocational Education of the National Academy of Pedagogical Sciences of Ukraine. Kyiv [in Ukrainian].

18. Subotnik, R. F., Olszewski-Kubilius, P., \& Worrell, F. C. (2011). Rethinking giftedness and gifted education: a proposed direction forward based on psychological science. Psychological science in the public interest, 12(1), 3-54 [in English].

Tkachenko L. I., orcid.org/0000-0002-2303-1147

\section{TEACHER'S READINESS FOR PEDAGOGICAL SUPPORT OF GIFTED STUDENTS IN THE CONTEXT OF EDUCATIONAL PRACTICE}

The article considers the problem of teacher's readiness for pedagogical support of gifted students in general secondary education institutions. The author analyzes the concept of readiness, based on the intelligence of well-known Ukrainian scientists, and agrees with them that this phenomenon is a complex synthetic formation, which is formed in pedagogical activity. The author also notes that the pedagogical support of gifted students is essentially an innovative activity, as the segment of education that directly cares for gifted students is insignificant.

In order to visualize the content of the studied problem, the author uses a modeling methodology. Convincingly presented approaches to the creation of a pedagogical model allow the author to minimize the visual range and at the same time to fill it with the content load. The model of teacher's readiness for pedagogical support presented in the article clearly demonstrates the structure of the phenomenon and the main communicative connections that play a leading role in its formation.

The author attaches special importance to the operational aspect of the teacher's readiness to provide pedagogical support to gifted children and youth. Emphasis is placed on the need for special knowledge about giftedness, its types and manifestations in children, the characteristics of the gifted contingent, ways to develop giftedness and more.

Particular emphasis is placed on the communicative competence of the teacher, which is a component of productive cooperation with students in their personal development. Based on the results of the experimental sites of the Institute of Gifted Children of the National Academy of Pedagogical Sciences of Ukraine, it is stated that the policy of general secondary education is aimed at finding and developing gifted children and combining efforts of teaching staff, administration and socio-psychological service to achieve a common goal - the development of gifted students.

Key words: giftedness, pedagogical support, teacher's readiness, structural model, general secondary education institution. 